\title{
Evaluation of mycotoxin sequestering agents for aflatoxin and deoxynivalenol: an in vitro approach
}

\author{
Changsu Kong, Seung Youp Shin and Beob Gyun Kim
}

\begin{abstract}
An experiment was conducted to determine the efficacy of mycotoxin sequestering agents for binding or degrading aflatoxin B1 (AFB1) and deoxynivalenol (DON) by an in vitro method. Ten toxin binder products including 5 bentonite clays (bentonite $A, B, C, D$, and E), 2 cellulose products (cellulose $A$ and $B$ ), a yeast cell wall, an activated charcoal, and a mixture product containing minerals, microorganisms, and phytogenic substances were used in this experiment. An in vitro procedure was used to mimic the digestive process in pigs. The binding ability for AFB1 of the cellulose products was less compared with the values of other sequestering products $(p<0.05)$. The percent adsorption of AFB1 by bentonite clays, cellulose products, yeast cell wall product, activated charcoal product, and the mixture product were 92.5 (average of 5 bentonite products), -13.5 (average of 2 cellulose products), 92.7, 100.2, and 96.6, respectively. The respective values for DON were 3.24, $11.6,22.9,14.4$, and 4.3 . In conclusion, most toxin sequestering agents used in the present study had potential to bind AFB1 rather than DON based on the in vitro study which simulated the $\mathrm{pH}$ condition of the gastrointestinal tract of pigs.
\end{abstract}

Keywords: Mycotoxin; Swine; Mycotoxin adsorbent

\section{Introduction}

Dietary mycotoxins have been shown to cause detrimental effects in swine health and production. Aflatoxin and deoxynivalenol (DON) are produced by molds such as Aspergillus and Fusarium, respectively, and are frequently found in feedstuffs in swine diets (Council for Agricultural Science and Technology, 2003). Recent studies employing meta-analytical approach indicated that aflatoxin and DON depressed the growth performance of pigs (Andretta et al. 2012; Mok et al. 2013).

Several methods have been used to overcome detrimental effects of mycotoxins from contaminated feedstuffs. These include the thermal inactivation and irradiating as physical method, treatment with acid/base solutions, ozonation, and ammoniation as chemical method, and degradation of toxins by microorganisms as biological method (Diaz and Smith 2005). In feed industry, toxin sequestering agents have been frequently

\footnotetext{
* Correspondence: bgkim@konkuk.ac.kr

Department of Animal Science and Technology, Konkuk University, Seoul 143-701, Republic of Korea
}

used because of its economic feasibility and suitability for nutritional perspective.

Several in vitro methods have provided a good idea of binding affinity and capacity, consequently have been used as a screening method for potential mycotoxin sequestering agents (Diaz et al. 2002; MarroquinCardona et al. 2009). However, these methods may not be directly applicable to pig diets because they did not use the successive incubation at different $\mathrm{pH}$ conditions similar to the intestinal environment of pigs. Thus, the objective of this experiment was to determine the binding efficacy of various sequestering agents to mycotoxins by an in vitro method which mimicked the gastrointestinal condition of pigs.

\section{Materials and methods Sequestering agents}

Ten toxin binder products including 5 bentonite clays (bentonite A, B, C, D, and E), 2 cellulose products (cellulose A and B), a yeast cell wall product, an activated charcoal product, and a mixture product consisted of minerals, microorganism, and phytogenic substances were used in this experiment.

\section{实}




\section{Toxin preparation}

The standard solution of AFB1 $(2 \mu \mathrm{g} / \mathrm{mL})$ and DON $(100.2 \mu \mathrm{g} / \mathrm{mL}$ ) in acetonitrile (Romer Labs Diagnostic $\mathrm{GmbH}$, Tulln, Austria) were diluted to 10 and $250 \mathrm{ng} / \mathrm{mL}$ using distilled water, respectively. The quantification ranges of enzyme-linked immunosorbent assay (ELISA) kit used for analysis on AFB1 and DON were from 2 to 50 and 250 to $5,000 \mathrm{ng} / \mathrm{mL}$, respectively.

\section{In vitro procedure}

An in vitro procedure was modified from suggested in vitro digestion procedure which simulates the digestion procedure of pigs (Boisen and Fernández 1997). Each sample consisted of $2.5 \mathrm{~mL}$ of phosphate buffer $(0.1 \mathrm{M}, \mathrm{pH} 6.0)$ and $0.5 \%$ suspension of each sequestering agent was transferred to $50 \mathrm{~mL}$ conical tube and $5 \mathrm{~mL}$ of diluted mycotoxin standard solution was added to the conical tube. For control treatment, $5 \mathrm{~mL}$ of phosphate buffer added. The $\mathrm{pH}$ was adjusted to $\mathrm{pH} 2.0$ by adding $300 \mu \mathrm{L} 1 \mathrm{M} \mathrm{HCl}$ for simulating $\mathrm{pH}$ in the stomach. Then each sample was incubated for $2 \mathrm{~h}$ in shaking incubator at $39^{\circ} \mathrm{C}$. The incubation of samples was conducted in triplicates of each sequestering agent sample. After 2-h incubation, $1 \mathrm{~mL}$ of phosphate buffer $(0.2 \mathrm{M}, \mathrm{pH} 6.8)$ was added to the conical tube. For simulating the conditions in the small intestine, $300 \mu \mathrm{L}$ of $1 \mathrm{M}$ $\mathrm{NaOH}$ was also added and incubated at $\mathrm{pH} 6.8$ for $4 \mathrm{~h}$. After incubation, the mixture was centrifuged and the supernatant was obtained for analysis of residual unbound AFB1 and DON. The AgraQuant ${ }^{\circ}$ Aflatoxin B1 (COKAQ8000) or Deoxynivalenol (COKAQ4000) ELISA test kits (Romer Labs Inc., Singapore) were used to detect the residual unbound AFB1 or DON concentration, respectively.

\section{Calculations and statistical analyses}

The percent adsorption of AFB1 and DON by sequestering agents was calculated using the following equation:

$$
\text { Percent adsorption }=(\text { IMT-UMT }) \div \mathrm{IMT} \times 100
$$

where IMT $(\mathrm{ng} / \mathrm{mL})$ is the initial amount of mycotoxin (AFB1 or DON) in the digestion conical tube; UMT (ng/ $\mathrm{mL}$ ) is the residual amount of unbound mycotoxin (AFB1 or DON) in the conical tube after digestion procedure.

Data were analyzed by MIXED procedure of SAS (SAS Inst. Inc., Cary, NC, USA). The model included the sequestering agent as a fixed variable. Differences among least squares means were determined by the PDIFF option with the Tukey's adjustment. The significance was declared at an alpha-level of 0.05 .

\section{Results and discussion}

The percent adsorption of AFB1 by various sequestering agents is presented in Table 1. The residual amount of
Table 1 In vitro percent adsorption of aflatoxin by various sequestering agents*

\begin{tabular}{lccc}
\hline $\begin{array}{l}\text { Sequestering } \\
\text { agent }\end{array}$ & \multicolumn{2}{c}{ Amount of aflatoxin, $\mathbf{n g} / \mathbf{m L}$} & $\begin{array}{c}\text { Aflatoxin } \\
\text { adsorption, \% }\end{array}$ \\
\cline { 2 - 3 } Initial & Unbound $^{\mathbf{1}}$ & 0 \\
Control & 10.00 & $94.3^{\mathrm{a}}$ \\
Bentonite A & $0.57^{\mathrm{c}}$ & $80.9^{\mathrm{a}}$ \\
Bentonite B & $1.91^{\mathrm{c}}$ & $94.4^{\mathrm{a}}$ \\
Bentonite C & $0.57^{\mathrm{c}}$ & $99.2^{\mathrm{a}}$ \\
Bentonite D & & $0.08^{\mathrm{c}}$ & $93.7^{\mathrm{a}}$ \\
Bentonite E & 10.00 & $0.63^{\mathrm{c}}$ & $-31.0^{\mathrm{c}}$ \\
Cellulose A & & $13.09^{\mathrm{a}}$ & $4.0^{\mathrm{b}}$ \\
Cellulose B & & $9.60^{\mathrm{b}}$ & $92.7^{\mathrm{a}}$ \\
Yeast cell wall & & $0.73^{\mathrm{c}}$ & $100.2^{\mathrm{a}}$ \\
Activated charcoal & & $-0.02^{\mathrm{c}}$ & $96.6^{\mathrm{a}}$ \\
Mixture $^{2}$ & & $0.34^{\mathrm{c}}$ & 5.06 \\
SEM & & 0.51 & $<0.001$ \\
p-value $^{3}$ & - & $<0.001$ &
\end{tabular}

*Each least squares mean represents three observations.

${ }^{1}$ Calculated in comparison to the control treatment containing no sequestering agent.

${ }^{2}$ The mixture product consisted of minerals, microorganism, and phytogenic substances.

${ }^{3}$ Standard error of the means.

${ }^{\mathrm{a}-\mathrm{b}}$ Values within a column without a common superscript letter $\operatorname{differ}(p<0.05)$.

Table 2 In vitro percent adsorption of deoxynivalenol by various sequestering agents*

\begin{tabular}{|c|c|c|c|}
\hline \multirow[t]{2}{*}{$\begin{array}{l}\text { Sequestering } \\
\text { agent }\end{array}$} & \multicolumn{2}{|c|}{$\begin{array}{c}\text { Amount of } \\
\text { deoxynivalenol, } \mathrm{ng} / \mathrm{mL}\end{array}$} & \multirow[t]{2}{*}{$\begin{array}{l}\text { Deoxynivaleno } \\
\text { adsorption, \% }\end{array}$} \\
\hline & Initial & Unbound $^{1}$ & \\
\hline Control & & 250.00 & 0 \\
\hline Bentonite A & & $242.21^{a b}$ & $3.1^{a b}$ \\
\hline Bentonite B & & $243.57^{\mathrm{ab}}$ & $2.6^{a b}$ \\
\hline Bentonite C & & $242.90^{\mathrm{ab}}$ & $2.8^{\mathrm{ab}}$ \\
\hline Bentonite D & & $247.40^{a}$ & $1.0^{b}$ \\
\hline Bentonite E & 250.00 & $233.13^{a b}$ & $6.7^{\mathrm{ab}}$ \\
\hline Cellulose A & & $234.28^{a b}$ & $6.3^{a b}$ \\
\hline Cellulose B & & $207.94^{\mathrm{ab}}$ & $16.8^{a b}$ \\
\hline Yeast cell wall & & $192.85^{b}$ & $22.9^{\mathrm{a}}$ \\
\hline Activated charcoal & & $213.94^{\mathrm{ab}}$ & $14.4^{\mathrm{ab}}$ \\
\hline Mixture $^{2}$ & & $239.32^{a b}$ & $4.3^{a b}$ \\
\hline $\mathrm{SEM}^{3}$ & - & 13.98 & 5.59 \\
\hline$p$-value & - & 0.019 & 0.019 \\
\hline
\end{tabular}

*Each least squares mean represents three observations.

${ }^{1}$ Calculated in comparison to the control treatment containing no sequestering agent.

${ }^{2}$ The mixture product consisted of minerals, microorganism, and phytogenic substances.

${ }^{3}$ Standard error of the means.

${ }^{\mathrm{a}-\mathrm{b}}$ Values within a column without a common superscript letter $\operatorname{differ}(p<0.05)$. 
unbound AFB1 was greater in cellulose products treatment than in the rest of sequestering products $(p<0.05)$. The percent adsorption of AFB1 by bentonite clays, cellulose, yeast cell wall product, activated charcoal product, and the mixture product were 92.5 (average of 5 bentonite products), -13.5 (average of 2 cellulose products), 92.7, 100.2, and 96.6, respectively. The binding ability for AFB1 of the cellulose products was less compared with the values of other sequestering products $(p<0.05)$. With exception of the cellulose products, the percent adsorption of AFB1 by the sequestering agents used in the current study was generally high and this result agrees with the previous in vitro study in which binding ability of aforementioned products were over 90\% (Diaz and Smith 2005). In addition, several in vivo study including pigs and broilers have shown that the sequestering agents ameliorated the detrimental effect of AFB1 (Schell et al. 1993; Miazzo et al. 2000; Raju and Devegowda 2000; Rosa et al. 2001). But, it is unclear why the percent adsorption of AFB1 by cellulose products was very low or negative. However, an overestimation of myxotoxins may occur if there are matrix effects of cellulose products on the detection of AFB1 because the target compounds are not antigens but mycotoxins in the present ELISA assay (Trucksess and Koeltzow 1995).

The amount of residual unbound DON after digestion procedure was lower in yeast cell wall products $(p<0.05)$ than bentonite $\mathrm{D}$ but it did not differ from the values of other products (Table 2). The low DONbinding ability of sequestering agents in the present work agrees with the result from an in vitro assay study in which the potential binders including mineral clays, humic substances and yeast-derived products were tested for the binding ability of DON and zearalenone by using a conventional incubation followed by a specific bioassay for mycotoxin detection (Sabater-Vilar et al. 2007). The percent adsorption of DON by bentonite clays, cellulose, yeast cell wall product, activated charcoal product, and the mixture product were 3.24 (average of 5 bentonite products), 11.6 (average of 2 cellulose products), 22.9, 14.4, and 4.3, respectively. The sequestering ability for DON of yeast cell wall product was greater than that of bentonite $\mathrm{D}(p<0.05)$. Most sequestering agents except cellulose products were relatively lower in ability for sequestering DON compared with AFB1 (average 7.2 vs. 94.0\%). This result was in agreement with the result observed in the previous study (Avantaggiato et al. 2005). Bentonite has been known as a good and selective adsorbent for AFB1 rather than DON (Phillips 1999) and this has been shown in the reported in vivo study in which the addition of bentonite with $0.5 \%$ modified yeast cell wall to the naturally DON-contaminated diets did not play a significant role in detoxification of DON (Shehata et al. 2004). This was also in agreement with the binding activity of bentonite in the current study as well as the values from the previous in vitro study (Avantaggiato et al. 2004). In contrast, activated charcoal adsorbed $14.4 \%$ DON from $1.25 \mu \mathrm{g} / \mathrm{mL}$ toxin in the current study, whereas the respective value was $87.7 \%$ (average of 3 observations) from $2.00 \mu \mathrm{g} / \mathrm{mL}$ toxin in other in vitro study which used the dynamic in vitro model simulating the GI-tract conditions of pigs (Avantaggiato et al. 2004).

In conclusion, the present study showed that most sequestering agents tested had sufficient potential to bind AFB1 rather than DON based on the in vitro experiment which mimicked the $\mathrm{pH}$ condition of the gastrointestinal tract of pigs.

\section{Competing interests}

The authors declare that they have no competing interests.

\section{Authors' contributions}

CK: Wrote most of the manuscript and contributed to the calculation and analysis of the data. SYS: Designed and performed experiments. BGK: Supervised the experimental work and manuscript preparation. All authors read and approved the final manuscript.

\section{Acknowledgements}

The authors are grateful for the support by Rural Development Administration (Republic of Korea; PJ008405). The paper resulted from the Konkuk University research support program.

Received: 9 April 2014 Accepted: 26 June 2014

Published: 8 July 2014

\section{References}

Andretta I, Kipper M, Lehnen CR, Hauschild L, MM, Lovatto PA (2012) Meta-analytical study of productive and nutritional interactions of mycotoxins in growing pigs. Animal 6:1476-1482

Avantaggiato G, Havenaar R, Visconti A (2004) Evaluation of the intestinal absorption of deoxynivalenol and nivalenol by an in vitro gastrointestinal model, and the binding efficacy of activated carbon and other adsorbent materials. Food Chem Toxicol 42:817-824

Avantaggiato G, Solfrizzo M, Visconti A (2005) Recent advances on the use of adsorbent materials for detoxification of Fusarium mycotoxins. Food Addit Contam A 22:379-388

Boisen S, Fernández JA (1997) Prediction of the total tract digestibility of energy in feedstuffs and pig diets by in vitro analyses. Anim Feed Sci Technol 68:277-286

Council for Agricultural Science and Technology (2003) Mycotoxins: Risks in Plant, Animal, and Human Systems. Council for Agric Sci Technol Task Force Report No. 139, Ames, IA, pp 58-63

Diaz DE, Smith TK (2005) Mycotoxin sequestering agents: Practical tools for the neutralisation of mycotoxins. In: Diaz DE (ed) The Mycotoxin Blue Book. Nottingham University Press, Nottingham, United Kingdom, pp 323-339

Diaz DE, Hagler WM, Hopkins BA Jr, Whitlow LW (2002) Aflatoxin Binders I: In vitro binding assay for aflatoxin B1 by several potential sequestering agents. Mycopathologia 156:223-226

Marroquin-Cardona A, Deng Y, Taylor JF, Hallmark CT, Johnson NM, Phillips TD (2009) In vitro and in vivo characterization of mycotoxin-binding additives used for animal feeds in Mexico. Food Addit Contam 26:733-743

Miazzo RD, Rosa CAR, Carvalho ECQ, Magnoli C, Chiacchiera SM, Palacio G, Saenz M, Kikot A, Basaldella E, Dalcero M (2000) Efficacy of synthetic zeolites to reduce the toxicity of aflatoxin in broiler chicks. Poult Sci 79:1-6

Mok CH, Shin SY, Kim BG (2013) Aflatoxin, deoxynivalenol, and zearalenone in swine diets: Predictions on growth performance. Rev Colomb Cienc Pecu 26:243-254

Phillips TD (1999) Dietary clay in the chemoprevention of aflatoxin-induced disease. Toxicol Sci 52:118-126 
Raju MVLN, Devegowda G (2000) Influence of esterified-glucomannan on performance and organ morphology, serum biochemistry and haematology in broilers exposed to individual and combined mycotoxicosis (aflatoxin, ochratoxin and T-2 toxin). Br Poult Sci 41:640-650

Rosa CAR, Miazzo R, Magnoli C, Salvano M, Chiacchiera SM, Ferrero S, Saenz M, Carvalho ECQ, Dalcero A (2001) Evaluation of the efficacy of bentonite from the South of Argentina to ameliorate the toxic effects of aflatoxin in broilers. Poult Sci 80:139-144

Sabater-Vilar M, Malekinejad H, Selman MHJ, van der Doelen MAM, Fink-Gremmels J (2007) In vitro assessment of adsorbents aiming to prevent deoxynivalenol and zearalenone mycotoxicoses. Mycopathologia 163:81-90

Schell TC, Lindemann MD, Kornegay ET, Blodgett DJ, Doerr JA (1993)

Effectiveness of different types of clay for reducing the detrimental effects of aflatoxin-contaminated diets on performance and serum profiles of weanling pigs. J Anim Sci 71:1226-1231

Shehata S, Richter W, Schuster M, Lindermayer H (2004) Effect of deoxynivalenol (DON) on growing pigs and its modification by modified yeast cell wall or modified yeast cell wall and bentonite. Mycotoxin Res 20:42-48

Trucksess MW, Koeltzow DE (1995) Evaluation and application of immunochemical methods for mycotoxins in food. In: Nelso JO, Karu AE, Wong RB (eds) Immunoanalysis of Agrochemical in Emerging Technologies. American Chemical Society, Washington DC, pp 326-334

doi:10.1186/2193-1801-3-346

Cite this article as: Kong et al:: Evaluation of mycotoxin sequestering agents for aflatoxin and deoxynivalenol: an in vitro approach.

SpringerPlus 2014 3:346.

\section{Submit your manuscript to a SpringerOpen ${ }^{\circ}$ journal and benefit from:}

- Convenient online submission

- Rigorous peer review

- Immediate publication on acceptance

- Open access: articles freely available online

- High visibility within the field

- Retaining the copyright to your article

Submit your next manuscript at $\gg$ springeropen.com 